\title{
Recenzja książki Iwony Koszewskiej $O$ depresji dziś (z serii Choroby mózgu)
}

Choroby mózgu - rozumiane jako schorzenia mające lokalizację w mózgu (niezależnie od definicji diagnostycznych), czyli neurologiczne i psychiatryczne - stanowią najczęstszą przyczynę niepełnosprawności. Na rynku wydawniczym pojawiła się seria wyjątkowych książek pod wspólnym tytułem Choroby mózgu. PZWL Wydawnictwo Lekarskie i redaktorzy naukowi serii, czyli prof. Tadeusz Parnowski (psychiatra) i prof. Maria Barcikowska (neurolog), zapraszają do współpracy wybitnych polskich naukowców i praktyków, by przybliżyć Czytelnikom osiągniecia nauki XXI w. dotyczące tego najbardziej (nadal) nieznanego organu ludzkiego ciała. Do tej pory w serii ukazały się książki dotyczące udaru mózgu, stwardnienia rozsianego i choroby Parkinsona.

Najnowsza pozycja z serii jest zatytułowana $O$ depresji $d z i s$. Autorka, dr n. med. Iwona Koszewska, lekarz psychiatra z wieloletnim stażem, wiele lat pracowała pod kierunkiem prof. Stanisława Pużyńskiego. Jest autorką i współautorką kilkudziesięciu prac naukowych na temat depresji, a także książek oraz poradników dla chorych i ich rodzin. Doktor Koszewska pisze o sobie, że największą satysfakcję zawodową czerpie z pracy z pacjentami.

W swojej najnowszej i najobszerniejszej książce ta wieloletnia praca naukowa i pełna zaangażowania i pasji praca kliniczna pozwoliły na przedstawienie depresji w sposób szczególny. Książka to zapis rozmów, w których autorka z charakterystycznym dla niej ciepłem, spokojem, w atmosferze bliskości i zrozumienia porusza temat depresji we współczesnym świecie.

Każda rozmowa to inne ujęcie depresji, stąd w książce depresja jest przedstawiona $\mathrm{z}$ wielu perspektyw. Doktor Iwona Koszewska rozmawia o współczesnej depresji z pacjentami i ich bliskimi, z lekarzami, psychoterapeutami, naukowcami, socjologami, antropologiem, pisarzem, scenarzystką, wykładowcami, organizatorami kampanii społecznych, nauczycielami. Każdy z rozmówców to zdaniem autorki ekspert, którego warto wysłuchać.

W książce bardzo interesujące są rozważania o niedoskonałości stosowanego współcześnie paradygmatu diagnostycznego. Kolejni rozmówcy wraz z dr Koszewską omawiają wiedzę na temat przyczyn powstawania depresji. Opowiadają o tym m.in. psychiatra, genetyk, neuropsycholog - każda perspektywa wnosi coś do całości obrazu, ale nadal nie wiemy wszystkiego, więc obraz pozostaje niedokończony. Psychiatra (prof. Janusz Rybakowski) przybliża czytelnikom i autorce kierunki współczesnych badań nad różnicowaniem i leczeniem depresji. Genetyk (prof. Joanna Pawlak) opowiada o ograniczeniach badań genetycznych. Profesor Alina Borkowska, neuropsycholog, zwraca uwagę na zmiany, jakie w ostatnim czasie zachodzą w rozumieniu funkcjonowaniu mózgu: z perspektywy modułowej (przypisanie konkretnych funkcji do danych struktur) dzięki rozwojowi neuronauk przeszliśmy do prób odtworzenia mapy sieci funkcjonalnych, połączeń w mózgu.

O swoich przeżyciach opowiadają pacjenci oraz ich bliscy. Oprócz samego pacjenta mamy okazję poznać także jego żonę, ponieważ, jak pisze autorka, to również „jej depresja”. Rozpoznawanie depresji to często zadanie lekarza rodzinnego - swoimi doświadczeniami podzielili się lekarze specjaliści medycyny rodzinnej (Jadwiga Brzosko i Ewa Gryczuk). Ciekawie i żywo prowadzone rozmowy dotyczą czasów, w których żyjemy, przyczyn depresji, postępów nauki, paradygmatu diagnostycznego, przeżycia depresji, współchorobowości. Oprócz poznawania i zrozumienia depresji, najważniejszym przesłaniem książki jest: „można pomóc”. Autorka wraz ze wszystkimi rozmówcami wskazuje, że można: rozpoznać, leczyć, zapobiegać. Jakże ważne jest to, co uwidacznia się we wszystkich rozdziałach - „nie jesteś sam”. Nie jest sam ani pacjent, ani jego bliscy. 
Z zainteresowaniem sięgnęłam po nową książkę dr Koszewskiej. Wcześniej czytałam dwie inne pozycje jej autorstwa: $O$ depresji, o manii, o nawracajacych zaburzeniach nastroju oraz $O$ depresji $w$ ciqży i po porodzie - obie moim zdaniem obowiązkowe na półce nie tylko psychiatry, lecz także każdego lekarza. I tak jak wtedy, także tym razem - było warto. Z każdej strony książki, każdego rozdziału, rozmowy przebija ogromna wrażliwość autorki na cierpienia chorych oraz chęć poznawania, rozumienia, niesienia pomocy. Polecam książkę młodym adeptom psychiatrii - tak wiele można się nauczyć od samej autorki i jej rozmówców - ale również osobom zmagającym się z depresją swoją czy swoich bliskich. I każdemu, kto chce się dowiedzieć więcej „o depresji dziš”.

dr hab. n. med. Dorota Eojko

Klinika Psychiatrii Dorostych

Uniwersytet Medyczny im. K. Marcinkowskiego w Poznaniu e-mail:lojko@ump.edu.pl

\section{Literatura}

1. Koszewska I. O depresji, o manii, o nawracających zaburzeniach nastroju. PZWL, Warszawa 2011.

2. Koszewska I. O depresji w ciąży i po porodzie. PZWL, Warszawa 2010.

3. Sienkiewicz-Jarosz H. Udar mózgu. Kompendium dla praktyka. PZWL, Warszawa 2020.

4. Friedman A. Choroba Parkinsona. Od mechanizmów do leczenia. PZWL, Warszawa 2019.

5. Bonek R. Stwardnienie rozsiane. Od chemokin do przeciwciał monoklonalnych. PZWL, Warszawa 2019. 